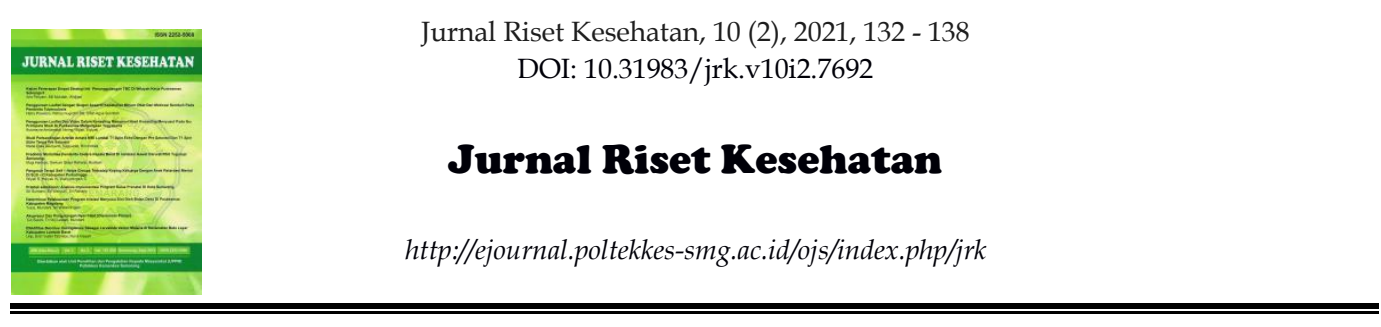

\title{
PERCEPTIONS OF TRADITIONAL MEDICINES FOR SELF-MEDICATION AMONG PEOPLE IN DIENG PLATEAU CENTRAL JAVA PROVINCE, INDONESIA
}

\author{
Aris Widayatia $^{{ }^{*}}$; Damiana Sapta Candrasari ${ }^{\mathrm{b}}$; Lusia Jois Mariana ${ }^{\mathrm{c}}$; Veronika $^{\mathrm{d}}$ \\ ${ }^{a}$ Faculty of Pharmacy; Sanata Dharma University ; Affandi street ; \\ Mrican Yogyakarta 55281 ; Indonesia
}

\begin{abstract}
Traditional medicines are commonly used in the community. One type of traditional medicines that is popular among people is "jamu". "Jamu" can be made from plants, animals, minerals, or a mixture of them that has been used for generations based on empiric experience. This study aimed to describe perceptions of the use of traditional medicines for self-medication among people in Dieng Plateau, Kejajar, Wonosobo, Central Java Province. This is a descriptive study with a qualitative approach. Respondents were adults more than 18 years old who had experience in using traditional medicines and were selected with non-random accidental sampling. Thirty-one (31) respondents signed informed consent. Data were collected using an interview guideline and analyzed using enumerative approach. Most of the respondents used traditional medicines for self-medication one to five times a month. They expressed that traditional medicine is like "Jamu", primarily liquid, with limited or no side effects. Traditional medicine was mostly obtained from local groceries at affordable prices. Most of the respondents have a positive attitude towards the use of traditional medicines. They have the willingness to use traditional medicines to deal with their symptoms or minor illnesses. Their satisfaction experience in using traditional medicine will motivate them to do so in the future. Based on the results, it can be said that traditional medicines have an important role in the health care system particularly for self-medication.
\end{abstract}

Keywords: Perception; Rural population; Self-medication, Traditional medicines

\section{Introduction}

Self-medication behavior is common among the Indonesian people. A study in Yogyakarta City involved 640 respondents found that $50 \%$ of the respondents did self-medication once time during the last month, $33 \%$ was twice, and $17 \%$ was more than twice. About $14 \%$ of the respondents mentioned they used traditional medicines, including fresh herbs (Widayati, 2013).

Self-medication behavior tends to increase because of the trend of back to nature spirit and go green concept (Tilaar et al., 2010). A national survey held by the Indonesia Ministry of Health

\footnotetext{
*) Corresponding Author (Aris Widayati)

E-mail: ariswidayati@usd.ac.id
}

in 2013 named "Riset Kesehatan Dasar" (Riskesdas) found that $15.7 \%$ of households in Indonesia kept traditional medicines in their house (KEMENKES RI, 2013).

Internal factors influence individual behavior in using medicines. For examples, socio-cognitive, knowledge, attitude, motivation, intention, and beliefs (Conner \& Norman, 2005). Many previous studies in Indonesia show the relationships between the individual factors and behavior of using traditional medicines for self-medication. For instances, beliefs about local wisdoms among Tidung community in Tarakan (Lesmana et al., 2018); beliefs on several traditional ways for hypertension treatment among Bengkulu society (Ervina \& Ayubi, 2018); socio-cultures that affect decision in using 
traditional medicines among community members in Aceh Besar (Ismail, 2015); and positive attitudes toward the use of herbs among academic staffs in a private university in West Java (Ismarani, 2013).

Indonesia is a country with plentiful of biodiversity. Some of them are medicinal plants that can be used for the medication (Tilaar et al., 2010). The use of herbs or medicinal plants is common, particularly among villagers and people in remote areas (Rahayu et al., 2002). A study revealed that the use of traditional medicines is higher among rural people than the urban (Supardi et al., 2005). People living in rural areas usually grow herb plants in their back yard for their daily uses. Traditional medicine products can also be easily found in small groceries in villages. People tend to consider traditional medicines are safe and have fewer side effects compared to conventional medicines (Awad \& Al-Shaye, 2014; Harmanto \& Subroto, 2007). The use of natural materials from plants has become local wisdom and has been empirically used as a legacy from the older generation (Ervina \& Ayubi, 2018; Rahayu et al., 2002; Suswardany et al., 2015; Zhang, 2000).

Dieng Plateau is a village in a tourism area in Kejajar Sub-district, District of Wonosobo, Central Java Province, which is commonly visited by both domestic and international tourists (Pokja Sanitasi Kabupaten Wonosobo, 2012). This unique situation inevitably creates interaction between the local people and the tourists. Transfer knowledge and experiences could happen in such an interaction, including the use of traditional medicines. This phenomenon is interesting since such interaction can provide external factors that affect individual behavior in using traditional medicines. Therefore, this study aimed to explore Dieng people's perceptions regarding the use of traditional medicines for self-medication.

\section{Method}

This is an observational descriptive study with a qualitative approach. Participants were people of Dieng Plateau, Sub-district of Kejajar, District of Wonosobo, Central Java Province. The inclusion criteria of participants were those who are adults (more than 18 years old) and had experience of self-medication using traditional medicines during the last month of the data collection and agreed to voluntary participation in this study by signing informed consent. Participants of this study were recruited using a non-random accidental technique (Moser \& Korstjens, 2018).

The interview method was applied to gather data from the recruited participants. The interviews were conducted face to face and guided by interview guideline. The interview guideline contained several open-ended questions regarding knowledge, attitude, intention, motivation, and pattern of behavior of using traditional medicines for self-medication. The guideline has been validated using expert judgment for the content and has been tested for the language. The interviews were audio-taped subject to participants' agreement and written in a minutes meeting.

Results of the interviews were transcribed verbatim in accordance with the minutes meeting. Two of the research team members conducted the data transcription independently to ensure data objectivity and accuracy. Data were then analyzed using enumerative approach, as follows: 1) labeling or coding the data, 2) selecting the data into the appropriate category, i.e.: knowledge and attitude, and 3) counting frequency and percentage of each category (Elo \& Kyngäs, 2008). The results of this qualitative study are written based on the Standard for Reporting Qualitative Research (SRQR) to engage the trustworthiness of the design, data collection and analysis, and reporting $\left(\mathrm{O}^{\prime}\right.$ Brien et al., 2014).

Ethical clearance of this study was obtained from the Ethics Committee of the Faculty of Medicine Gadjah Mada University Yogyakarta with. No. Ref: KE/FK/706/EC/2015. Research permits were approved by Badan Kesatuan Bangsa dan Perlindungan Masyarakat (Badan Kesbanglinmas) No.: 074/1286/Kesbang/ 2014.

\section{Result and Discussion}

A number of thirty one participants involved in this study. Participants' characteristics are described in Table 1. Female participants were dominant (68\%). Most of the participants were in the age range of 32 to 38 $(38 \%)$. Most of them were married $(84 \%)$. Most of them had a senior high school education level $(45 \%)$. Most of them were a trader $(36 \%)$ and farmer $(32 \%)$. The range of monthly income was 
mostly between 1.000 .000 IDR to 1.500 .000 IDR $(32 \%)$.

Tabel 1. Characteristics of the participants involved in the study in Dieng Plateau, Sub-district of Kejajar, District of Wonosobo, Central Java Province

\begin{tabular}{lc}
\hline \multicolumn{1}{c}{ Participant's characteristics } & $\begin{array}{c}\text { Percentage (\%); } \\
\text { N=31 }\end{array}$ \\
\hline Gender & 68 \\
Female & 32 \\
Male & \\
\hline Range of age (year) & 23 \\
18-24 & 16 \\
25-31 & 32 \\
$32-38$ & 13 \\
39-45 & 10 \\
46-52 & 6 \\
53-59 & $33(18-59)$ \\
Median of age & \\
\hline Marital status & 84 \\
Married & 16 \\
Not married & \\
\hline Education level & 23 \\
Elementary school & 29 \\
Junior high school & 45 \\
Senior high school & 3 \\
University & \\
\hline Employment status & 3 \\
Do not have a job or household & \\
mother & 13 \\
Employee & 36 \\
Trader & 3 \\
Civil servant & 32 \\
Farmer & 16 \\
\hline Monthly income (IDR) & 32 \\
< 300.000 & \\
300.000 - 1.000.000 & \\
1.000.000 -1.500.000 & \\
1.500.000 -2.000.000 & \\
> .000.000 & \\
Do not have any income & \\
\hline & \\
\hline
\end{tabular}

Participants' perceptions of traditional medicines can be seen in Table 2 . The results show that most of the participants (36\%) mentioned traditional medicines as "Jamu". Most of them believed that traditional medicines do not contain chemicals (32\%). Most of them $(84 \%)$ perceived those traditional medicines do not have any side effects. Most of them (87.1\%) mentioned the liquid when they were questioned about the dosage form of traditional medicines they are familiar with.

The popularity of "Jamu Gendong" among the Indonesian people perhaps lead to a perception that associating traditional medicines to "Jamu". In fact, "Jamu Gendong" is one particular name given to traditional medicines sold by a seller who is normally a woman door to door in the neighborhood. It usually includes at least these particular items, i.e.: "Beras Kencur", "Kunir Asem", "Brotowali". The sellers used to sell all those particular items using a traditional bucket (called: "Tenggok" in Javanese language) and used to carry the bucket in their back. That is why this kind of traditional medicines called "Jamu Gendong" ("Gendong" is a term in the Javanese language that means carrying something in the back using a bucket) (Tilaar et al., 2010, 2011). Nowadays, the seller rides the bicycle or motorcycle to sell these types of traditional medicines door to door and do not use traditional bucket anymore.

The perception that traditional medicine is "Jamu" as found in this reported study is similar to the finding of the previous study that involved women in Kabupaten Wonogiri Jawa Tengah (Widayati \& Wulandari, 2018). The term of "Jamu" is obviously popular among the society members as it has been used and acknowledged from generation to generation. "Jamu" has been used since long years ago. The use of "Jamu" is mostly based on empirical experience (Tilaar et al., 2010).

Table 2. Participants' perceptions about traditional medicines.

\begin{tabular}{|c|c|}
\hline $\begin{array}{l}\text { Participants' perceptions about } \\
\text { traditional medicines }\end{array}$ & $\begin{array}{l}\text { Percentage (\%), } \\
\quad \mathrm{N}=31\end{array}$ \\
\hline \multicolumn{2}{|c|}{$\begin{array}{l}\text { Question 1: “What is your perception regarding traditional } \\
\text { medicines? }\end{array}$} \\
\hline It is what we call "Jamu" & 36 \\
\hline $\begin{array}{l}\text { It does not contain any chemical } \\
\text { substances because it is composed of } \\
\text { natural sources only, such as curcumin }\end{array}$ & 32 \\
\hline $\begin{array}{l}\text { Traditional medicines have no side } \\
\text { effects }\end{array}$ & 16 \\
\hline $\begin{array}{l}\text { It is like herbal plants that can be } \\
\text { obtained from our backyard, for } \\
\text { example Purwoceng, Ginger. }\end{array}$ & 16 \\
\hline It can be made at home from the herbs & 10 \\
\hline It is like Tolak Angin ${ }^{\circledR}$ & 3 \\
\hline \multicolumn{2}{|c|}{$\begin{array}{l}\text { Question 2: "What do you think about the side effects of traditional } \\
\text { medicines?" }\end{array}$} \\
\hline They do not have side effects & 84 \\
\hline They have side effects & 16 \\
\hline \multicolumn{2}{|c|}{$\begin{array}{l}\text { Question 3: "What kind of dosage form of traditional medicines } \\
\text { that you are familiar with?" }\end{array}$} \\
\hline Liquid & 87 \\
\hline Solid & 33 \\
\hline
\end{tabular}

Nowadays, "Jamu" is produced by Pharmaceutical companies and is labeled with a specific label authorized by the Indonesia Food and Drug Administration (Badan Pengawasan Obat dan Makanan /BPOM) (BPOM RI, 2004). Yet, "Jamu Gendong" remains popular among 
society. Supardi et al in 2010 reported that about $17.4 \%$ of the individuals in 33 provinces in Indonesia used "Jamu" that were prepared from plants or herbs. They reported that Sand Ginger (the local name is "Kencur"), Ginger, and Turmeric (the local name is "Temulawak") were the most popular herbs for "Jamu" (Supardi et al., 2011).

Table 3. Participants' evaluation regarding the use of traditional medicines

\begin{tabular}{|c|c|c|}
\hline $\begin{array}{l}\text { Evaluation regarding the } \\
\text { use of traditional medicines }\end{array}$ & $\begin{array}{l}\text { Response of } \\
\text { the } \\
\text { evaluation (+ } \\
\text { / -) }\end{array}$ & $\begin{array}{l}\text { Percentage } \\
(\%), N=31\end{array}$ \\
\hline It has good effects & + & 45.2 \\
\hline It has no side effects & + & 16.1 \\
\hline It has a long onset of effect & + & 12.9 \\
\hline It is natural & + & 6.5 \\
\hline $\begin{array}{l}\text { It is better than the } \\
\text { medicines sold in groceries }\end{array}$ & + & 6.5 \\
\hline It can cure a disease totally & + & 6.5 \\
\hline It is affordable & + & 3.2 \\
\hline It has limited side effects & + & 3.2 \\
\hline $\begin{array}{l}\text { It is appropriate for minor } \\
\text { illness }\end{array}$ & + & 3.2 \\
\hline $\begin{array}{l}\text { It is affordable and } \\
\text { accessible }\end{array}$ & + & 3.2 \\
\hline It can minimize symptoms & + & 3.2 \\
\hline It can cure quickly & + & 3.2 \\
\hline $\begin{array}{l}\text { It has benefit and risk as } \\
\text { well }\end{array}$ & $+/-$ & 3.2 \\
\hline $\begin{array}{l}\text { It is better to see a doctor } \\
\text { than using traditional } \\
\text { medicines }\end{array}$ & - & 3.2 \\
\hline
\end{tabular}

As described in Table 3, participants' attitude can be positive or negative. Most of the participants evaluated their use of traditional medicines positively (45.2\%). Table 4 shows most participants liked to use of traditional medicines $(87 \%)$. Based on results described in Table 3 and 4 , it can be said that generally most of the participants have a positive attitude towards the use of traditional medicines.

Table 4. Participants' attitude regarding the use of traditional medicines

\begin{tabular}{lc}
\hline \multicolumn{1}{c}{ Participants' responses } & $\begin{array}{c}\text { Percentage } \\
(\%), \mathrm{N}=31\end{array}$ \\
\hline $\begin{array}{l}\text { The use of traditional medicines is } \\
\text { favorable (positive attitude) }\end{array}$ & 87 \\
\hline $\begin{array}{l}\text { The use of traditional medicines is not } \\
\text { favorable (negative attitude) }\end{array}$ & 13 \\
\hline
\end{tabular}

This result is in line with a study among herbs consumers in West Java Province (Ismarani, 2013). An individual would likely to have a positive attitude when he/she holds a certain belief and experiences a benefit regarding the belief (Conner \& Norman, 2005). In the context of using traditional medicines, the results of this study show that most of the participants believed the traditional medicines they used were free from a chemical substance, without any side effects, and cheap. Also, they can easily find herbs in their back yard. A previous study among Mandar ethnic community in South Sulawesi also found similar themes regarding perception about traditional medicines given by traditional healers in that area (Rachman \& Wardhana, 2011). When people had experienced a positive outcome resulted from the traditional medicines they used, then they would have a positive attitude towards such use. The positive attitude towards the use of traditional medicines possessed by the people will tend to create a motivation to use traditional medicines.

There is an interesting finding revealed by this study which has been conducted in Dieng Plateau. Yet Pimpinella alpina Molk., which is named Puwaceng as its local name, is an endemic plant in the Plateau, people in that area do not often use this plant. Instead of using the plant for themselves, people in the area preferred selling the plant to the tourists visited the Plateau. They did some efforts to keep the plant well-preserved (Darwati \& Roostika, 2006). It is well known that Purwaceng (Pimpinella alpina Molk.) has the main effect as an aphrodisiac, besides other effects such as diuretic and tonic. The aphrodisiac effect of the Purwaceng obviously attracts people to visit the Plateau because the plant is difficult to be found in another area. The Plateau community members seem to use the Purwaceng as one of the main commercial commodities to be sold to the visitors, and therefore as the main source of income.

\section{Conclusion and Suggestion}

Based on the results of this study, it can be concluded that "Jamu" has become the most popular traditional medicines known by most participants. They perceived those traditional medicines were safe and without side effects, no chemical substance, and cheap. The participants had a positive attitude towards the use of traditional medicines. Therefore, further action is required specially to optimize the use of herbs or traditional medicines among the community. Further research could be an intervention study 
aimed to improve the appropriate use of traditional medicines.

\section{Acknowledgments}

The authors would like to acknowledge: 1) the LPPM Universitas Sanata Dharma for providing the research funding through the Internal Research Grant scheme in 2015, with the grant No: 028/PeneILPPM USD/IV/2015; 2) the participants of this study; 3 ) the undergraduate students' team as the data collectors.

\section{References}

Awad, A., \& Al-Shaye, D. (2014). Public awareness, patterns of use and attitudes toward natural health products in Kuwait: A cross-sectional survey. BMC Complementary and Alternative Medicine. https://doi.org/10.1186/1472-6882-14-105

BPOM RI. (2004). Keputusan Kepala Badan Pengawas Obat dan Makanan Republik Indonesia Nomor HK.00.05.4.2411 tentang Ketentuan Pokok Pengelompokan dan Penandaan Obat Bahan Alam.

Conner, M., \& Norman, P. (2005). Predicting Health Behaviour: Research and Practice with Social Cognition Models. In Predicting Health Behaviour (pp. 127 - 160). https://doi.org/10.1016/S0925-7535(97)814 83-X

Darwati, I., \& Roostika, I. (2006). Status of Research in Purwoceng (Pimpinella alpina Molk.) In Indonesia. Buletin Plasma Nutfah, 12(1), $\quad 9 \quad-15$. https://doi.org/10.21082/blpn.v12n1.2006. p9-151

Elo, S., \& Kyngäs, H. (2008). The qualitative content analysis process. Journal of Advanced Nursing, 62(1), $107-115$. https://doi.org/10.1111/j.1365-2648.2007.0 4569. $x$

Ervina, L., \& Ayubi, D. (2018). Peran Kepercayaan Terhadap Penggunaan Pengobatan Tradisional Pada Penderita Hipertensi Di Kota Bengkulu. Perilaku Dan Promosi Kesehatan, 1(1), 1-9.

Harmanto, N., \& Subroto, M. A. (2007). Pilih Jamu dan Herbal Tanpa Efek Samping. PT. Elex Media Komputindo Gramedia.

Ismail. (2015). Faktor Yang Mempengaruhi Keputusan Masyarakat Memilih Obat Tradisional Di Gampong Lam Ujong. Idea Nursing Journal, VI(1), 7-14.
Ismarani. (2013). Kajian Persepsi Konsumen Terhadap Penggunaan Obat Herbal ( Kasus di Unisma Bekasi). CEFARS; Jurnal Agribisnis Dan Pengembangan Wilayah, 4(2), 52-63.

KEMENKES RI. (2013). Riset Kesehatan Dasar (RISKESDAS) 2013. In Kemenkes RI (Issue 1). https://doi.org/10.1007/s13398-014-0173-7. 2

Lesmana, H., Alfianur, Utami, P. A., Retnowati, Y., \& Darni. (2018). Pengobatan Tradisional Pada Masyarakat Tidung Kota Tarakan: Studi Kualitatif Kearifan Lokal Bidang Kesehatan. MEDISAINS: Jurnal Ilmiah Ilmu Ilmu Kesehatan, 16(1), 31-41.

Moser, A., \& Korstiens, I. (2018). Series: Practical guidance to qualitative research. Part 3: Sampling, data collection and analysis. European Journal of General Practice, 24(1), 9 18.

https:// doi.org/10.1080/13814788.2017.137 5091

Pokja Sanitasi Kabupaten Wonosobo. (2012). Buku Putih Sanitasi Kabupaten Wonosobo Provinsi Jawa Tengah.

Rachman, W. A., \& Wardhana, R. A. (2011). Perilaku Etnik Mandar Terhadap Pengobatan Tradisional di Kabupaten Polewali Mandar (Studi Perilaku dengan Pendekatan Etnografi di Kecamatan Balanipa, Kabupaten Polewali Mandar). MKMI, 7(2), 93-104.

Rahayu, M., Rugayah, Praptiwi, \& Hamzah. (2002). Keanekaragaman pemanfaatan tumbuhan obat oleh suku Sasak di Taman Nasional Gunung Rinjani-Nusa Tenggara Barat. Prosiding Simposium Nasional II Tumbuhan Obat Dan Aromatik.

Supardi, S., Herman, M. J., \& Yuniar, Y. (2011). Penggunaan Jamu Buatan Sendiri di Indonesia (Analisis Data Riset Kesehatan Dasar Tahun 2010). Buletin Penelitian Sistem Kesehatan, 14(4), 375-381.

Supardi, S., Jamal, S., \& Raharni. (2005). Pola Penggunaan Obat, Obat Tradisional dan Cara Tradisional dalam Pengobatan Sendiri di Indonesia. Bul. Penel. Kesehatan, 33(4), 192-198.

Suswardany, D. L., Sibbritt, D. W., Supardi, S., Chang, S., \& Adams, J. (2015). A critical review of traditional medicine and traditional healer use for malaria and among people in malaria-endemic areas: Contemporary research in low to 
middle-income Asia-Pacific countries. In Malaria Journal. https://doi.org/10.1186/s12936-015-0593-7

Tilaar, M., Wih, W. ., \& Setiadi-Rianti, A. (2011). Pioneers in Green Science (Beberapa Model Penerapan Konsep Ramah Lingkungan di Indonesia). Dian Rakyat.

Tilaar, M., Wih, W. L., \& Ranti, A. S. (2010). The Green Science of Jamu. Dian Rakyat.

Widayati, A. (2013). Swamedikasi di Kalangan Masyarakat Perkotaan di Kota Yogyakarta.
Jurnal Farmasi Klinik Indonesia, 2(4).

Widayati, A., \& Wulandari, E. T. (2018). Edukasi
Manfaat
Tanaman
Obat
dan

Pengolahannya dengan Metode CBIA di Desa Bulusulur, Kabupaten Wonogiri, Jawa Tengah. Abdimas Altruis: Jurnal Pengabdian Kepada Masyarakat, 1(1), 25-30.

Zhang, X. (2000). General Guideline for Methodologies on Research and Evaluation of Traditional Medicine. World Health Organisation. 